nical and constructive advice. In view of the clash and overlapping between general economic and social questions, the pamphlet appears to be dubious as to the continued existence of the Intermational Labour Organisation as an entity, though this is not made clear. It is suggested, however, that the whole of the positive functions of the Economic and Social Council of the Dumbarton Oaks plan for constructing peace, as distinct from preventing war, should be discharged by bodies corresponding to those set up in 1918an assembly, or conference, a council or goverming body, and a secretariat or office, with committees to provide technical advice as required. The council would include representatives of the workers as well as governments and would take the place of the governing body of the International Labour Organisation. Its functions would include determining the agenda of the assembly, which itself would not be limited to government representatives. The secretariat would be divided into departments dealing, for example, with conditions of labour, with economic problems, with health and housing, with dependent territories and so forth, but with close inter-departmental relations. This plan would telescope the constructive functions of the old League of Nations secretariat and those of the International Labour Office, while employers or managers would find their place along with other professional men in the special committees created to advise on technical and practical issues. Although the Dumbarton Oaks plan is now, of course, submerged in the United Nations Charter, this pamphlet provides useful material for careful consideration.

\section{Religion and Science}

THE conventional "conflict between religion and science" has concerned itself with questions which are not of themselves fundamental, and which are consequently incapable, as they stand, of any solution, as their perpetual recurrence indicates. The truth is, in Prof. H. Dingle's view, "that most of us have two different, and largely incompatible, attitudes towards what is essentially a homogeneous body of experience, and that we are, in the main, unconscious of this" " "Science and Religion." Modern Pamphlets on Religion, Life and Thought, No. 5. Union of Modern Free Churchmen, 92 Blake Road, London, N.11. 6d.). Both scientific and religious interpretations, in spite of their divergence from one another, are "attempts to interpret experience in rational terms". Their difference lies in their being concerned, in the main, with different kinds of experience, so that the interpretations which in either case seem most suitable are different. The scientific descriptions of the world are most appropriate for the particular limited fields of experience with which the respective seiences deal. The religious descriptions are those most appropriate for the different but also limited fields of experience with which religions deal. As knowledge grows, it may be expected that the two descriptions "will develop and ultimately coalesce into a single description capable of expressing all experience": though we need not expect this ultimate description "to be identical with, or even greatly to resemble, any of the descriptions we can at present give" ; and we shall therefore regard without concern any incompatibility between religious and scientific thought to-day. For we must recognize that the time has not yet come when we can construct a single comprehensive world-picture that will interpret all experience. We must be content with partial pictures, each limited to the experiences which pro. vide its justification.

\section{The Night Sky in September}

NEw moon occurs on Sept. 6d. 13h. 43m. U.T. and full moon on Sept. 2ld. 20h. 46m. The following conjunctions with the moon take place: Sept. 2d. 1lh., Saturn $1^{\circ}$ S. ; Sept. 3d. 11h., Venus $3^{\circ}$ S. ; Sept. 4d. 22h., Mercury $4^{\circ}$ S.; Sept. 8d. 00h., Jupiter $4^{\circ} \mathrm{S}$; ; Sept. 29d. 00h., Mars $0 \cdot 2^{\circ} \mathrm{S}$. ; Sept. 29 d. $20 \mathrm{~h}$., Saturn $2^{\circ} \mathrm{S}$. In addition to these conjunctions with the moon, the following conjunctions take place: Sept. 9d. 12h., Mercury in conjunction with Regulus, Mercury $0 \cdot 3^{\circ}$ N.; Sept. 23d. 19h., Venus in conjunction with Regulus, Venus $0.4^{\circ} \mathrm{N}$. Occultation of $\mu$ Gem $(D)$. takes place on Sopt. 1d. $3 \mathrm{~h} .39 \cdot 2 \mathrm{~m}$., and of $147 \mathrm{~B}$ Aries $(R)$ on Sept. 25 d. $3 \mathrm{~h} .10 \cdot 4 \mathrm{~m}$. On Sept. 29 there is a grazing occultation of 44 Gem. Mercury can be seen in the morning hours, rising at $3 \mathrm{~h}$. $51 \mathrm{~m} ., 4 \mathrm{~h} .13 \mathrm{~m}$. and $5 \mathrm{~h} .47 \mathrm{~m}$. at the beginning, middle and end of the month, respectively. The planet is at its greatest westerly elongation on Sept. 6. Venus can be seen in the morning hours, rising at $1 \mathrm{~h}$. $51 \mathrm{~m} ., 2 \mathrm{~h} .28 \mathrm{~m}$. and $3 \mathrm{~h} .07 \mathrm{~m}$. at the beginning, middle and end of the month respectively. Mars rises at $22 \mathrm{~h} .42 \mathrm{~m}$. on Sept. 1 and at $22 \mathrm{~h} .10 \mathrm{~m}$. on Sept. 30 . Jupiter is unfavourably placed for observation. Saturn rises at $0 \mathrm{~h}$. $5: \mathrm{m}$. at the beginning and at $23 \mathrm{~h} .12 \mathrm{~m}$. at the end of the month. Autumn equinox commences on Sept. 23d. 10h.

\section{Announcements}

A Conference on "Friedel-Crafts Catalysts and Polymerization" has been arranged at the Department of Chemistry, University of Manchester, to be held on September 15. Those taking part include Prof. M. Polanyi (Manchester), Dr. P. H. Sykes (I.C.I. Billingham), Prof. H. W. Melville (Aberdeen) and Prof. M. G. Evans (Leeds). Notification of attendance should reach Prof. Polanyi by September 1.

THE annual conference of the Association of Special Libraries and Information Bureaux will be held at the Portland Hall, London, W.C.1, during September 15-16. The opening address will be delivered by Prof. J. D. Bernal, who will speak on the information service as an essential factor in the progress of science ; there will also be a symposium on "Links with the U.S.A." and a discussion on the effects on education, research and cultural relations of the shortage of books. Application forms can be obtained from the office of the Association, 52 Bloomsbury Street, London, W.C.l.

The National Institute of Agricultural Engineering intends to recommence publication of the Agricultural Engineering Record, as a quarterly jourmal dealing with developments in the mechanization of agriculture. Publication was begun in 1940 , but ceased after the first number because of war-time difficulties. The Record will contain accounts of the research and development work carried out at the Institute ; and it is hoped that other workers in this field will also contribute to its pages. A new feature will be the inclusion of summaries of test reports issued by the Institute, when these have a general interest. The first number will appear in September, and thereafter on January 1, April 1, July 1 and October 1 each year (1s. per copy, or $4 s$. $4 d$. per year, post paid; subscriptions to the Secretary, National Institution of Agricultural Engineering, Askham Bryan, York; or to H.M. Stationery Office, York House, Kingsway, W.C.2). 